\title{
PENCEGAHAN PERMAINAN “STARTER” MELALUI PENDEKATAN PERSONAL SAFETY SKILL PADA MURID SEKOLAH DASAR
}

Trini Handayani

Pascasarjana Program Magister Ilmu Hukum dan Fakultas Hukum Universitas Suryakancana

E-mail: trinihandayani2012@gmail.com

\begin{tabular}{|l|l|l} 
Masuk : Maret 2017 & Penerimaan : Maret 2017 & Publikasi : Juni 2017
\end{tabular}

\begin{abstract}
ABSTRAK
Starter adalah permainan yang cenderung dilakukan oleh anak laki-laki, terutama pada anak di tingkat Sekolah Dasar. Anak yang menjadi korban maupun pelaku tidak menyadari bahaya permainan ini, yaitu, infeksi pada testis, kerusakan organ testis, bahkan kemandulan. Permainan starter dapat dikategorikan sebagai salah satu bentuk kekerasan seksual, karena permainan ini berhubungan langsung dengan organ reproduksi utama. Salah satu dari upaya pencegahan yang dilakukan adalah dengan mengajarkan keterampilan keselamatan pribadi untuk anak, metode ini dipopulerkan oleh Bagley dan King pada tahun 2004. Personal Safety Skills (keterampilan keselamatan pribadi) adalah keterampilan yang wajib dipahami oleh anak, sehingga mereka dapat menghindar dari kekerasan seksual dan situasi yang memungkinkan terjadinya kekerasan seksual.
\end{abstract}

Kata Kunci: Permainan Starter, Kekerasan Seksual, Personal Safety Skill.

\section{ABSTRACT}

Starter is a game made by boys, especially in children at the elementary level. This game often effects on victim. The victims and perpetrators are not aware of the occurrences impact of this game, that are, the infection of the testicles, testicular organ damage, and even infertility. Game starter can be categorized as a form of sexual violence, because it is directly related to the primary reproductive organs. One of the preventive efforts undertaken is to teach personal safety skills to children. This method is popularized by Bagley and King in 2004. Personal Safety Skills is a skill that must be understood by children, so that they can avoid violent offenders sexual and situations that allow sexual violence.

Keywords: Game Starter, Sexual Violence, Personal Safety Skills.

\section{A. PENDAHULUAN}

1. Latar Belakang

Beberapa waktu lalu, di media sosial beredar tentang permainan starter yang dilakukan pada anak tingkat Sekolah Dasar. Permainan starter terutama dilakukan pada anak lakilaki kepada anak laki-laki lain, meskipun ada yang dilakukan terhadap perempuan, tetapi kasusnya jarang sekali. Permainan ini dilakukan dengan cara, anak lakilaki sebagai korban disuruh membuka lebar pahanya dan teman laki-laki sebagai pelaku di depannya meletakkan telapak kaki di selangkangan anak laki-laki yang menjadi korban. Permainan starter dilakukan seperti menginjak gas dan membuat bunyi seperti sedang 
menstarter motor atau mobil dan memainkan kakinya mundur maju. Bagi korban yang kemaluannya distarter dalam waktu paling lama, korban tersebut menjadi juara. Permainan ini kadang-kadang ditonton oleh temannya dan menyemangati serta menikmati permainan starter ini.

Permainan ini sebagian besar dilakukan di sekolah, dan dilakukan pada waktu jam istirahat atau jam pulang sekolah. Dari wawancara awal Penulis kepada orang tua anak korban permainan starter, sekolah merupakan tempat berlangsungnya permainan starter (100\%).

Meskipun testis relatif ditutupi oleh skrotum, refleks kontraksi otot yang cukup baik dan liat, cedera tumpul (termasuk permainan starter) dapat mengakibatkan pecahnya tunika albuginea, memar, hematoma (perdarahan), dislokasi (testis berpindah tempat), atau torsi testis (testis berputar sehingga aliran darah terhambat). Cedera testis akibat trauma tumpul sebanyak $75 \%$ kasus. ${ }^{1}$

Kekerasan seksual menurut Mark Yantzi adalah suatu bentuk kekerasan yang terjadi karena persoalan seksualitas. Sorenson mendefinisikan kekerasan seksual sebagai perilaku yang dilakukan melalui pendekatan-pendekatan yang terkait dengan seks yang tidak diinginkan, termasuk permintaan untuk melakukan hubungan seks, dan perilaku lainnya yang secara verbal ataupun fisik merujuk pada aktivitas seksual. $^{2}$

McAninch et al, 1984; Cass dan Luxenberg Trauma Testis dan Kulit Genital, about.me/becks.urolog, diakses tgl 25 Februari 2017.

Rina Astuti, (2011), Hubungan Kesadaran Akan Kerentanan Diri dan Mekanisme Coping pada Perempuan Pekerja Malam di Tempat
Merujuk pendapat Mark Yantzi, permainan starter yang berhubungan dengan organ reproduksi secara langsung, dapat dikategorikan sebagai kekerasan seksual, meskipun hal ini tidak disadari baik oleh pelaku maupun oleh korban.

Pengajaran Personal Safety Skills merupakan salah satu metode dalam mencegah permainan starter di kemudian hari. Penjelasan yang lengkap dan terus terang akan membuat anak tidak penasaran dan tidak mencari informasi dari luar yang belum tentu kebenarannya.

Orang tua belum memahami pentingnya pendidikan seks sejak dini, sehingga anak melakukan permainan starter di sekolah tanpa menyadari dampak negatifnya. Menurut Bagley dan King, Personal Safety Skills atau keterampilan keselamatan pribadi merupakan seperangkat keterampilan yang perlu dikuasai oleh anak agar dapat menjaga keselamatan dirinya dan terhindar dari tindakan kekerasan seksual. ${ }^{3}$ Menurut beberapa penelitian, hasil pengajaran menggunakan metode Personal Safety Skills cenderung bertahan lama.

\section{Lokasi Pengabdian}

Pada Sekolah Dasar Islam Kreatif di Kabupaten Cianjur, di mana murid sekolah tersebut sebagian besar (sekitar 90\%) dari mulai kelas III sampai kelas $\mathrm{VI}$ sudah mengenal permainan starter, baik sebagai korban maupun sebagai pelaku.

Hiburan Karaoke Wilayah Jakarta Barat, Jurnal Kriminologi Indonesia Vol. 7 No. II Oktober, hlm. 194.

Esya Anesty Mashudi, Nur'aini, (2015), Pencegahan Kekerasan Seksual Pada Anak Melalui Pengajaran Personal Safety Skills, Metodik Didaktik Vol. 9, No. 2, Januari, hlm. 66. 
Sebagian pelaku ada yang sudah duduk di bangku Sekolah Menengah Pertama (SMP).

\section{Peserta}

Kelas I sampai kelas VI, sejumlah 418 (empat ratus delapan belas) murid. Apabila ada murid yang berhalangan hadir, diikutkan pada kelas berikutnya, begitu seterusnya, sehingga semua murid mendapatkan pembelajaran tentang Personal Safety Skills. Waktu pembelajaran dibagi menjadi 6 (enam) hari sesuai dengan jumlah kelas.

\section{B. METODE}

Berawal dari maraknya pemberitaan di media massa mengenai permainan starter di Sekolah Dasar, orang tua murid SD kelas 5 menyampaikan bahwa dari 32 (tiga puluh dua) orang tua, 30 (tiga puluh) orang tua menyampaikan bahwa anaknya pernah melakukan permainan starter, baik sebagai pelaku, korban maupun sebagai pelaku dan korban. Pelaku permainan starter biasanya anak yang dulu pernah menjadi korban kakak kelasnya dan kemudian mempraktikkan kepada teman atau adik kelas.

Selain itu, Penulis juga melakukan wawancara dengan karyawan yang berada di lingkungan Penulis bekerja. Hasil wawancara yang dilakukan dengan 10 (sepuluh) responden, 9 orang mengaku sudah pernah melakukan permainan starter (mereka menjawab dengan setengah malu, karena saya sebagai pewawancara berjenis kelamin perempuan) dan hanya 1 orang yang mengatakan belum tahu permainan tersebut dan tidak pernah merasakan permainan tersebut pada waktu kecil. Sebagian besar mengaku, permainan tersebut dilakukan pada waktu menjadi murid di Sekolah Dasar dan sebagian kecil ada yang berlanjut sampai Sekolah Menengah Pertama.

\section{PEMBAHASAN}

\section{Perlindungan Anak}

Hak asasi anak merupakan bagian dari hak asasi manusia yang termuat dalam Undang-Undang Dasar 1945 (UUD 1945) dan ketentuan Konvensi Hak Anak (Convention on the Rights of the Child) yang diratifikasi oleh pemerintah Indonesia melalui Keputusan Presiden Nomor 36 Tahun 1990 (Keppres 36/ 1990), kemudian juga dituangkan dalam UndangUndang Nomor 4 Tahun 1979 (UU 4/ 1979) tentang Kesejahteraan Anak dan Undang-Undang Nomor 23 Tahun 2002 (UU 23/ 2002) jo Undang-Undang Nomor 35 Tahun 2014 (UU 35/ 2014) tentang Perlindungan Anak yang kesemuanya mengemukakan prinsip-prinsip umum perlindungan anak, yaitu non diskriminasi, kepentingan terbaik bagi anak, kelangsungan hidup dan tumbuh kembang, dan menghargai partisipasi anak. ${ }^{4}$

Mengacu pada peraturan tersebut, Beijing Rules memberikan ramburambu tentang batas usia anak tidak ditetapkan dalam usia yang terlalu rendah. Seseorang belum dapat dipertanggungjawabkan perbuatannya secara pidana apabila belum dewasa secara emosional, dewasa secara mental dan dewasa secara intelektual. 5 Menurut Beiijing Rules, tujuan peradilan bagi remaja adalah, pertama, kasus kejahatan remaja agar ditangani oleh

Nur Hidayati, (2014), Perlindungan Anak terhadap Kejahatan Kekerasan Seksual (Pedofilia), Ragam Jurnal Pengembangan Humaniora Vol. 14 No. 1, April, hlm. 69.

Waluyadi (2009), Hukum Perlindungan Anak, Bandung, Mandar Maju, hlm. 41-42. 
peradilan keluarga, apabila terpaksa harus ditangani oleh peradilan kriminal, faktor kesejahteraan anak harus mendapat perhatian. Kedua adalah prinsip kesepadanan, visi yang hendak dicapai dalam peradilan anak menurut Beiijing Rules adalah (1) untuk mencapai kesejahteraan anak; (2) Penjatuhan pidana pada anak, tidak harus bersifat menghukum; (3) dalam menjatuhkan hukuman terhadap anak harus berdasarkan prinsip-prinsip: a. Tidak berdasarkan pada kejahatan yang telah dilakukan, b. Penjatuhan pidana hendaknya memperhatikan kondisi yang menyebabkan seorang anak melakukan kejahatan, c. Dimungkinkan pemberian ganti rugi sebagai pengganti hukuman, dan $d$. Rasa penyesalan anak yang diwujudkan dalam bentuk kesediaannya untuk kembali ke jalan yang benar dapat menjadi alasan pemaaf untuk tidak dijatuhinya hukuman. ${ }^{6}$

Peningkatan kasus kekerasan anak yang terjadi di Indonesia dianggap sebagai salah satu indikator buruknya kualitas perlindungan anak. Keberadaan anak yang belum mampu untuk hidup mandiri tentunya sangat membutuhkan orang-orang sebagai tempat berlindung. Rendahnya kualitas perlindungan anak di Indonesia banyak menuai kritik dari berbagai elemen masyarakat. Pertanyaan yang sering dilontarkan adalah sejauh mana pemerintah telah berupaya memberikan perlindungan (hukum) pada anak sehingga anak dapat memperoleh jaminan atas kelangsungan hidup dan penghidupannya sebagai bagian dari hak asasi manusia. Padahal, berdasarkan Pasal 20 UU 23/2002 jo UU $35 / 2014$, yang berkewajiban dan

Waluyadi (2009), Hukum, ... Ibid, hlm 45-46 bertanggungjawab terhadap penyelenggaraan perlindungan anak adalah negara, pemerintah, masyarakat, keluarga, dan orang tua. ${ }^{7}$

Mendidik anak pada hakekatnya merupakan usaha nyata dari pihak orang tua untuk mengembangkan totalitas potensi yang ada pada diri anak. Masa depan anak di kemudian hari akan sangat tergantung dari pengalaman yang didapatkan anak termasuk faktor pendidikan dan pola asuh orang tua. Di saat sekarang ini tidak sedikit orang tua yang mengejar kepentingan sendiri dengan dalih untuk kesejahteraan anak, sehingga terkadang peran mereka sebagai orangtua yaitu mendidik dan mengasuh anak terabaikan. ${ }^{8}$

Peran orang tua sangat besar untuk memberikan penjelasan kepada anak, sehingga perlu dibentuk sikap yang positif dari orang tua terutama ibu tentang pentingnya pendidikan seksual untuk anak. Sikap yang positif akan membantu ibu dalam mendampingi anak memberikan penjelasan tentang seksualitas yang benar sesuai dengan tahapan perkembangan anak. Pendidikan seksual perlu diberikan sejak anak usia dini apalagi pada saat ini banyak sekali anak di bawah umur yang menjadi korban eksploitasi seksual. Untuk anak usia 3-5 tahun pendidikan seksual yang sesuai

Vina Kartikasari, (2013), Tinjauan Yuridis Tentang Urgensi Perlindungan Hukum Terhadap Anak Sebagai Korban Tindak Pidana Perkosaan, Skripsi, Universitas Brawijaya, hlm. 8.

8 Joko Tri Suharsono, Aris Fitriyan, Arif Setyo Upoyo, (2009), Hubungan Pola Asuh Orang Tua terhadap Kemampuan Sosialisasi Pada Anak Prasekolah di TK Pertiwi Purwokerto Utara, Jurnal Keperawatan Soedirman (The Soedirman Journal of Nursing), Vol. 4, No. 3, November, hlm. 1. 
adalah dengan mengenalkan bagian anggota tubuh anak beserta dengan fungsinya masing-masing, menjelaskan perbedaan antara anak laki-laki dan perempuan serta menjelaskan sensasi yang dirasakan pada alat kelaminnya. ${ }^{9}$

Menurut Ricard J. Gelles, kekerasan terhadap anak merupakan perbuatan disengaja yang menimbulkan kerugian atau bahaya terhadap anak-anak (baik secara fisik maupun emosional). Bentuk kekerasan terhadap anak dapat diklasifikasikan menjadi kekerasan secara fisik, kekerasan secara psikologi, kekerasan secara seksual dan kekerasan secara sosial. Kekerasan seksual terhadap anak menurut End Child Prostitution in Asia Tourism (ECPAT) Internasional merupakan hubungan atau interaksi antara seorang anak dengan seorang yang lebih tua atau orang dewasa seperti orang asing, saudara sekandung atau orang tua di mana anak dipergunakan sebagai objek pemuas kebutuhan seksual pelaku. Perbuatan ini dilakukan dengan menggunakan paksaan, ancaman, suap, tipuan bahkan tekanan. Kegiatan-kegiatan kekerasan seksual terhadap anak tersebut tidak harus melibatkan kontak badan antara pelaku dengan anak sebagai korban. Bentuk-bentuk kekerasan seksual itu sendiri bisa dalam tindakan perkosaan ataupun pencabulan. ${ }^{10}$ Permainan starter termasuk ke dalam pencabulan,

9 Inhastuti Sugiasih, (2011), Need Assessment "Mengenai Pemberian Pendidikan Seksual Yang Dilakukan Ibu Untuk Anak Usia 3-5 Tahun”, Jurnal Psikologi Proyeksi Vol. 6, No. 1 April, hlm. 71.

10 Ivo Noviana, (2015), Kekerasan Seksual terhadap Anak: Dampak dan Penangannya, Sosio Informa Vol. 01, No. 1, Januari-April, hlm. 15. meskipun tidak disadari oleh pelaku maupun korban.

Pemerintah bertanggung jawab untuk melindungi warga negaranya dari korban kekerasan seksual. Tetapi dalam kenyataannya, meskipun sudah ada jaminan peraturan yang mampu melindungi anak, namun fakta membuktikan bahwa peraturan tersebut belum dapat melindungi anak dari tindakan kekerasan seksual. Oleh karena itu, upaya yang harus menjadi prioritas utama (high priority) untuk melindungi anak dari tindakan kekerasan seksual adalah melalui reformasi hukum. Reformasi hukum yang harus dilakukan pertama kali adalah dengan cara mentransformasi paradigma hukum. Spirit untuk melakukan reformasi hukum dilandasi dengan paradigma pendekatan berpusat pada kepentingan terbaik bagi anak (a child-centered approach) berbasis pendekatan hak. Para praktisi hukum maupun pemerintah setiap negara selalu melakukan berbagai usaha untuk menanggulangi kejahatan dalam arti mencegah sebelum terjadi dan menindak pelaku kejahatan yang telah melakukan perbuatan atau pelanggaran atau melawan hukum. Usaha-usaha yang rasional untuk mengendalikan atau menanggulangi kejahatan sudah barang tentu tidak hanya dengan menggunakan hukum pidana, tetapi dapat juga menggunakan sarana non hukum pidana. Penanggulangan secara hukum pidana yaitu penanggulangan setelah terjadinya kejahatan atau menjelang terjadinya kejahatan, dengan tujuan agar kejahatan itu tidak terulang kembali. Penanggulangan secara hukum pidana dalam suatu kebijakan kriminal merupakan penanggulangan kejahatan dengan memberikan sanksi pidana bagi para pelakunya 
sehingga menjadi contoh agar orang lain tidak melakukan kejahatan. Berlakunya sanksi hukum pada pelaku, secara tidak langsung memberikan perlindungan kepada korban perkosaan anak di bawah umur ataupun perlindungan terhadap calon korban. Ini berarti memberikan hukuman yang setimpal dengan kesalahannya atau dengan kata lain para pelaku diminta pertanggungjawabannya. Upaya penanggulangan kejahatan dengan menggunakan sanksi hukum pidana merupakan cara yang paling tua, setua peradaban manusia itu sendiri. Sampai saat inipun, hukum pidana masih digunakan dan diandalkan sebagai salah satu sarana politik kriminal. Hukum pidana hampir selalu digunakan dalam produk legislatif untuk menakuti dan mengamankan bermacam-macam kejahatan yang mungkin terjadi. ${ }^{11}$

Upaya penanggulangan kejahatan melalui undang-undang (hukum) pidana pada hakikatnya merupakan bagian integral dari upaya perlindungan masyarakat (social defence). Kebijakan sosial (social policy) dapat diartikan sebagai usaha yang rasional untuk mencapai kesejahteraan masyarakat sekaligus mencakup perlindungan masyarakat, jadi di dalam pengertian social politic, di dalamnya mencakup social welfare politic, jadi tujuan akhir dari politik kriminal adalah perlindungan masyarakat untuk kesejahteraan masyarakat. ${ }^{12}$

Apabila dilihat dari perspektif politik kriminal secara makro, maka kebijakan penanggulangan

11 Ivo Noviana, Kekerasan Seksual,...Ibid, hlm. 23.

12 Barda Nawawi Arief, (1996), Bunga Rampai Kebijakan Hukum Pidana, Bandung, Citra Aditya Bakti, hlm. 5. kejahatan dengan menggunakan sarana di luar hukum pidana (nonpenal policy) merupakan kebijakan yang paling strategis. Hal ini disebabkan karena nonpenal policy lebih bersifat sebagai tindakan pencegahan terhadap terjadinya kejahatan, di mana sasaran utamanya adalah menangani dan menghapuskan factor-faktor kondusif penyebab terjadinya kejahatan. ${ }^{13}$

Kebijakan penanggulangan kejahatan atau politic criminal dapat meliputi ruang lingkup yang cukup luas. G. Peter Hoefnagels berpendapat bahwa kebijakan kriminal secara garis besar dapat dikelompokkan menjadi 2 (dua), yaitu: 1. Kebijakan kriminal dengan menggunakan sarana hukum pidana (penal policy) melalui criminal law application dan 2. Kebijakan kriminal dengan menggunakan sarana di luar hukum pidana (nonpenal policy) melalui influencing views of society on crime and punishment (mass media) dan prevention without punishment. Kedua sarana ini (penal dan nonpenal) merupakan pasangan satu sama lain yang tidak dapat dipisahkan, bahkan dapat dikatakan, keduanya saling melengkapi dalam usaha penanggulangan kejahatan di masyarakat. ${ }^{14}$

Salah satu upaya pencegahan permainan starter dapat dilakukan adalah melalui pengajaran personal safety skills atau keterampilan keselamatan pribadi pada anak. Hasil dari studi meta analisis yang

13 Supriyadi, Beberapa Catatan terhadap Kebijakan Legislatif dalam Perundang-undangan Pidana di Indonesia”, Mimbar Hukum no 40/ 11/ 2002, Majalah berkala Fakultas Hukum UGM, hlm. 20.

14 Hoefnagels GP (1973), The Other Side of Criminology, Holland, Kluwer B. V, Deventer, hlm 56. 
dilakukan Berrick and Barth (1992), diketahui bahwa pengetahuan yang diperoleh dari kelas personal safety skills ini cenderung bertahan lama. ${ }^{15}$ Orang tua merupakan ujung tombak perlindungan anak sebagaimana tercantum dalam Undang-Undang tentang Hak Asasi Manusia Pasal 26 ayat (2) yang berbunyi orang tua mempunyai hak pertama untuk memilih jenis pendidikan yang akan diberikan pada anaknya, artinya bahwa orang tua yang memutuskan tentang informasi maupun pendidikan yang terbaik bagi anak-anaknya, hal ini sejalan dengan UU 23/ 2002 jo UU 35/2014 Pasal 10 yang menyatakan bahwa setiap anak berhak menyatakan dan didengar pendapatnya, menerima, mencari, dan memberikan informasi sesuai dengan tingkat kecerdasan dan usianya demi pengembangan dirinya sesuai dengan nilai-nilai kesusilaan dan kepatutan.

\section{Personal Safety Skills}

Masa usia dini sering dikatakan sebagai masa keemasan atau The Golden Age Moment. Usia 0 sampai dengan 8 tahun adalah masa di mana anak memiliki kemampuan penyerapan informasi yang sangat pesat. Kepesatan kemampuan otak anak dalam menyerap berbagai informasi di sekitarnya juga diiringi dengan rasa ingin tahu yang sangat tinggi. Rasa ingin tahu yang sangat tinggi ditunjukkan anak dengan aktif bertanya tentang berbagai hal yang mereka temui, serta mencari tahu berbagai jawaban yang mereka inginkan dengan bereksplorasi. Salah

15 Esya Anesty Mashudi dan Nur'aini, (2015), Pengajaran personal safety skills dalam pencegahan kekerasan seksual pada anak, Metodik Didaktik Vol. 9, No. 2, Januari, hlm. 60-61. satu rasa ingin tahu yang sangat tinggi pada anak usia dini adalah berkaitan dengan seks. Seks sendiri menurut Santrock (2005) berhubungan dengan jenis kelamin laki-laki dan perempuan, jenis kelamin yang ditentukan secara biologis yang melekat pada jenis kelamin tertentu yang tidak dapat diubah karena perbedaan tersebut berlaku sepanjang zaman. Pada usia 4-6 tahun di mana kemampuan anak menyerap informasi yang luar biasa dan rasa ingin tahu anak yang sangat tinggi tersebut seiring dengan perkembangan peran seks yang berkembang pesat. Menurut Freud perkembangan seksual di masa kanak-kanak, terjadi pada usia 0-5 tahun. Rasa ingin tahu anak ini seharusnya mendapatkan penjelasan yang benar mengenai pengetahuan seksual. Pengetahuan seks yang keliru pada anak, akan menimbulkan persepsi yang keliru tentang alat kelamin, proses reproduksi, dan seksualitas. Hal ini dapat berdampak pada penyimpangan perlakuan seksual.

Pada perkembangan seksualitas anak kecil, antara lain ada 2 (dua) hal yang penting. Pertama, berdasarkan perkembangan yang dialami tentang seksualitas anak, tampaklah bahwa manusia bersifat biseksual artinya adanya perbedaan psikoseksual antara pria dan perempuan merupakan hasil dari perkembangan. Perbedaan tersebut sudah lengkap terjadi sejak permulaan pertama kehidupan manusia. Pada awalnya, anak kecil dapat mengenal 2 (dua) jenis kelamin, kemudian pada perkembangannya, terdapat ciri khas antara laki-laki dan perempuan, perbedaan jenis kelamin tersebut ditunjukkan oleh embriologi dan anatomi. Hal kedua yang nampak 
adalah fase perkembangan dengan zona erogen yang berbeda dalam tubuh manusia. Berturut-turut adalah mulut, anus, penis atau klitoris (kelentit) dan paling akhir vagina. Mula-mula seksualitas anak kecil bertumpu pada fungsi fisiologis yang paling elementer, seperti makan, dan buang air. Pada periode ini, seksualitas genital belum memainkan perannya. Pada awalnya, perkembangan tersebut dimulai dari fase oral, fase anal, fase falik dan akhirnya dengan melalui suatu perkembangan yang panjang dan berbelit, berakhir pada fase genital. ${ }^{16}$

Personal safety skills atau keterampilan keselamatan pribadi merupakan seperangkat keterampilan yang perlu dikuasai oleh anak agar dapat menjaga keselamatan dirinya dan terhindar dari tindakan kekerasan seksual. Personal safety skills terdiri atas 3 (tiga) komponen keterampilan yang dikenal dengan slogan 3 R yakni: Recognize, Resist, dan Report,. ${ }^{17}$

Anak seharusnya mengetahui bahwa tubuhnya merupakan miliknya dan tidak ada seseorang pun dapat menyentuhnya tanpa ijin dari dirinya sendiri. Mulainya membuka pembicaraan sejak dini tentang seksualitas dan "bagian tubuh yang privasi", dengan menggunakan nama yang sesuai dengan bagian tubuh genital dan bagian tubuh lainnya akan membantu anak untuk mengerti. Anak seharusnya dapat menolak dan berkata "TIDAK" dengan berani dan lantang pada kontak fisik yang tidak

16 Sigmund Freud, Ed. K. Bertens, (2005), Psikoanalisis, Jakarta, Pustaka Utama, hlm. 1920.

17 Esya Anesty Mashudi, Nur'aini, (2015), Pencegahan Kekerasan Seksual,... OP Cit, hlm. 66-67. sesuai, menghindar dari situasi yang tidak aman dan dapat mengadu pada orang dewasa. ${ }^{18}$

Peran masyarakat oleh media massa harus dilakukan dengan bijaksana demi perlindungan anak karena dalam UU 23/2002 ditegaskan dalam Pasal 64, "perlindungan dari pemberitaan identitas melalui media massa dan untuk menghindari labelisasi". Artinya dalam hal ini seharusnya masyarakat ikut membantu memulihkan kondisi kejiwaan korban. Masyarakat diharapkan ikut mengayomi dan melindungi korban dengan tidak mengucilkan korban, tidak memberi penilaian buruk kepada korban. Perlakuan semacam ini juga dirasa sebagai salah satu perwujudan perlindungan kepada korban, karena dengan sikap masyarakat yang baik, korban tidak merasa minder dan takut dalam menjalani kehidupan bermasyarakat. Berdasarkan atas beberapa teori di atas, merupakan salah satu bekal untuk melakukan pendidikan seks dan pengajaran Personal Safety Skills pada murid Sekolah Dasar dalam rangka pencegahan terhadap permainan starter yang dilakukan oleh murid Sekolah Dasar.

Kepala Sekolah pada salah satu Sekolah Dasar swasta di Kabupaten Cianjur, mendapat laporan dari murid tentang perlakuan temannya terhadap dirinya. Ada 4 (empat) murid yang melakukan permainan starter kepada temannya (korban). Korban dipanggil untuk klarifikasi mengenai hal tersebut, korban mengakui telah menjadi objek permainan starter oleh temannya

18 Dini Risty Justicia, (2016), Program Underwear Rules untuk Mencegah Kekerasan Seksual pada Anak Usia Dini, Jurnal Pendidikan Usia Dini Vol. 9 Edisi. 2, November, hlm. 224225. 
sendiri. Pelaku mengaku, pernah menjadi korban dari kakak kelasnya yang sekarang sudah menginjak Sekolah Menengah Pertama. Pada waktu ditanya akibat permainan tersebut, pelaku maupun korban menjawab tidak tahu sama sekali.

Berdasarkan fakta tersebut, Kepala Sekolah mengajukan permohonan untuk diadakan pengajaran seks di Sekolah Dasar tersebut dalam rangka antisipasi permainan starter. Pada waktu yang disepakati, para murid dikumpulkan di aula sesuai dengan tingkatan kelas untuk mendapat penjelasan tentang pengajaran seks dan Personal Safety Skills.

Tabel. 1.1

Data Jumlah Siswa Sekolah Dasar yang Mendapat Materi Personal

$$
\text { Safety Skill }
$$

\begin{tabular}{|c|c|c|}
\hline NO & KELAS & $\begin{array}{l}\text { JUMLAH } \\
\text { MURID }\end{array}$ \\
\hline 1 & I A, I B DAN I C & $30,28,29=87$ \\
\hline 2 & II A, II B DAN II C & $31,31,32=94$ \\
\hline 3 & III A DAN III B & $31,31=62$ \\
\hline 4 & IV A DAN IV B & $31,31=62$ \\
\hline 5 & V A DAN V B & $30,30=60$ \\
\hline 6 & VI A DAN VI B & $27,26=53$ \\
\hline \multicolumn{2}{|r|}{ J U M L A H } & 418 \\
\hline
\end{tabular}

Kegiatan dilaksanakan selama 6 (enam) hari sesuai dengan tingkatan. Ada beberapa murid yang berhalangan hadir, tetapi besoknya diikutkan kepada kelas yang lain.

Pada waktu pengajaran, selain didampingi oleh guru sekolah, kadang-kadang oleh Kepala Sekolah, Komite Sekolah juga mendampingi pengajaran tersebut dan membantu membagikan kuesioner atau soal yang disampaikan buat murid.

Adapun hal yang disampaikan adalah sebagai berikut:

a. Adanya perbedaan jenis kelamin, berikut organ tubuh reproduksi yang berbeda antara laki-laki dan perempuan; b. Adanya persamaan dan perbedaan organ tubuh antara anak laki-laki dan perempuan;

c. Terjadinya menstruasi pada wanita yang sudah baligh dan mimpi basah pada laki-laki yang sudah baligh, pada situasi ini, sudah mulai dicatat amalnya;

d. Adanya 4 (empat) organ tubuh (mulut, dada, organ sekitar selangkangan-alat kelamin dan pantat) yang tidak boleh disentuh oleh siapapun, kecuali orang tua, dokter apabila sedang sakit;

e. Berteriak "TIDAK" apabila ada orang yang mau menyentuh organ tubuh tersebut.

Metode pengajaran disampaikan sesuai dengan tingkatan kelas dan diselingi dengan menonton video, permainan serta gambar orang lakilaki maupun perempuan dan organ tubuh yang sama maupun berbeda antara laki-laki dan perempuan serta 4 (empat) organ tubuh mana yang tidak boleh disentuh oleh siapapun.

Bagi kelompok atau murid yang dapat menjawab pertanyaan narasumber dengan benar, diberi reward yang berkaitan dengan pembelajaran, seperti alat tulis, pensil warna, buku, buku cerita, dan sebagainya.

Pada waktu dilakukan evaluasi, semua murid menjawab dengan benar pertanyaan yang berkaitan dengan materi. Hasil pengajaran tersebut dilakukan evaluasi selama 1 (satu) bulan, permainan starter sudah tidak ditemukan lagi di Sekolah Dasar tersebut.

\section{PENUTUP}

1. Kesimpulan

Permainan starter sudah merupakan permainan yang dilakukan sejak lama, terutama pada anak laki-laki yang sedang menuntut ilmu di 
Sekolah Dasar. Pelaku maupun korban tidak menyadari bahaya yang ditimbulkan akibat permainan tersebut. Permainan ini disebut juga sebagai kekerasan seksual karena menyangkut organ reproduksi.

Salah satu upaya pencegahan dapat dilakukan melalui pengajaran personal safety skills atau keterampilan keselamatan pribadi pada anak. Evaluasi terhadap program pencegahan kekerasan seksual yang berbasis pengajaran personal safety skills menunjukkan bahwa baik anak usia sekolah maupun pra-sekolah mendemonstrasikan peningkatan pengetahuan dan keterampilan dalam menjaga keselamatan diri dari tindakan kekerasan seksual. Metode penyampaian pengajaran dengan video, gambar dan permainan ternyata merupakan media yang cukup berhasil dalam pengajaran ini.

\section{Saran}

Pendidikan personal safety skills pada anak balita dilaksanakan di posyandu dalam kegiatan Bina Keluarga Balita. Pendidikan ini dapat dijadikan program pemerintah, selain untuk mencegah teriadinya permainan starter sebagai kekerasan seksual atau pencabulan tanpa disadari oleh pelaku maupun korban, dapat juga dipakai untuk mencegah jenis kekerasan seksual lainnya pada anak, seperti pedofilia.

Pendidikan pencegahan kekerasan seksual pada anak di sekolah merupakan kewajiban pihak sekolah untuk menyelenggarakan kegiatan tersebut, mengingat anak sangat menghormati, menyayangi dan lebih menurut kepada guru yang mendidiknya.

\section{UCAPAN TERIMA KASIH}

Penulis ucapkan banyak terima kasih kepada Rektor Universitas Suryakancana atas segala support yang diberikan, dan kepada semua pihak yang terlibat di dalamnya dalam perlindungan terhadap anak di sekolah dasar.

\section{DAFTAR PUSTAKA}

\section{A. Buku}

Barda Nawawi Arief, (1996), Bunga Rampai Kebijakan Hukum Pidana, Bandung, Citra Aditya Bakti.

Hoefnagels GP (1973), The Other Side of Criminology, Holland, Kluwer B. V, Deventer.

Sigmund Freud, Ed. K. Bertens, (2005), Psikoanalisis, Jakarta, Pustaka Utama.
Waluyadi (2009), Hukum Perlindungan Anak, Bandung, Mandar Maju.

\section{B. Peraturan Undangan}

Perundang-

Undang-Undang Dasar 1945.

Undang-Undang Nomor 1 Tahun 1946 tentang Kitab UndangUndang Hukum Pidana.

Undang-Undang Nomor 4 Tahun 1979 tentang Kesejahteraan Anak.

Undang-Undang Nomor 39 tahun 1999 tentang Hak Asasi Manusia.

Undang-Undang Nomor 23 tahun 2002 tentang Perlindungan Anak. 
Undang-Undang Nomor 35 tahun 2014 tentang Perubahan Atas Undang-Undang No 23 tahun 2002.

\section{Jurnal}

Dini Risty Justicia, (2016), Program Underwear Rules untuk Mencegah Kekerasan Seksual Pada Anak Usia Dini, Jurnal Pendidikan Usia Dini Vol. 9 Edisi 2, November.

Esya Anesty Mashudi, Nur'aini, (2015), Pencegahan Kekerasan Seksual Pada Anak Melalui Pengajaran Personal Safety Skills, Metodik Didaktik Vol. 9, No. 2, Januari.

(2015), Pengajaran personal safety skills dalam pencegahan kekerasan seksual pada anak, Metodik Didaktik Vol. 9, No. 2, Januari.

Inhastuti Sugiasih, (2011), Need Assessment Mengenai

Pemberian Pendidikan Seksual Yang Dilakukan lbu Untuk Anak Usia 3-5 Tahun, Jurnal Psikologi Proyeksi, Vol. 6, No.1, April.

Ivo Noviana, (2015), Kekerasan Seksual terhadap Anak: Dampak dan Penanganannya, Sosio Informa Vol. 01, No.1, Januari-April.

Joko Tri Suharsono, Aris Fitriyan, Arif Setyo Upoyo, (2009), Hubungan Pola Asuh Orang Tua terhadap Kemampuan Sosialisasi Pada Anak Prasekolah di TK Pertiwi Purwokerto Utara, Jurnal Keperawatan Soedirman (The
Soedirman Journal of Nursing), Vol. 4, No. 3, November.

Lukman Hakim Nainggolan, (2009), Bentuk-Bentuk Kekerasan Seksual Terhadap Anak Di Bawah Umur, Jurnal Equality, Volume 13 Nomor 1 Februari.

M. Anwar Fuadi, (2011), Dinamika Psikologi Kekerasan Seksual: studi fenomenologi, PSIKOISLAMIKA, Jurnal Psikologi Islam (JPI) Copyright (C) 2011 Lembaga Penelitian Pengembangan Psikologi dan Keislaman (LP3K). Volume 8 Nomor 2, Januari.

Nur Hidayati, (2014), Perlindungan Anak terhadap Kejahatan Kekerasan Seksual (Pedofilia), Ragam Jurnal Pengembangan Humaniora Vol. 14, No. 1, April.

Rina Astuti, (2011), Hubungan Kesadaran Akan Kerentanan Diri dan Mekanisme Coping pada Perempuan Pekerja Malam di Tempat Hiburan Karaoke Wilayah Jakarta Barat, Jurnal Kriminologi Indonesia Vol. 7 No. II Oktober.

\section{Makalah, Skripsi, Tesis, atau Disertasi}

Vina Kartikasari, (2013), Tinjauan Yuridis Tentang Urgensi Perlindungan Hukum Terhadap Anak Sebagai Korban Tindak Pidana Perkosaan, Skripsi Universitas Brawijaya. 


\section{E. Karya Pengabdian Lepas (Website)}

McAninch et al, 1984; Cass dan Luxenberg Trauma Testis dan Kulit Genital, about.me/becks.urolog, diakses Tanggal 25 Februari 2017.
F. Koran, Majalah, atau Media Massa Lain

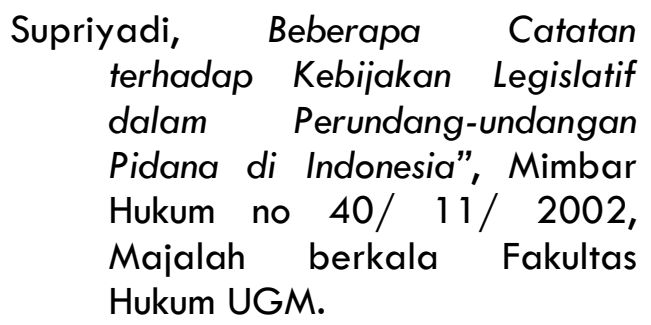

